\title{
Key to the families of decapod crustacean larvae collected off northern Chile during an El Niño event ${ }^{1}$
}

\author{
Pedro Báez \\ Sección Hidrobiología, Museo Nacional de Historia Natural \\ Casilla 787, Santiago, Chile
}

\begin{abstract}
Only 15 families of decapod crustaceans living as larvae in oceanic waters of northern Chile survived the strong impact of the El Niño 1982-83 event. A key considering only their most conspicuous external characters, without specimens dissection, is given. These families represent one third of the total reported for the area living under "normal" oceanographic conditions; and at the level of species the 22 collected are almost one seventh of their total of 150. Species introduced in the area with more septentrional waters belong to the families Penaeidae and Sicyoniidae. Collected larvae were mainly those from intertidal and sublittoral waters.
\end{abstract}

Key words: keys, decapod crustaceans, larvae, El Niño event, Chile.

\section{Clave de larvas de crustáceos decápodos recolectadas frente al norte de Chile durante un fenómeno EI Niño ${ }^{1}$}

\begin{abstract}
RESUMEN. Solo 15 familias de crustáceos decápodos representadas por larvas sobrevivieron la fuerte influencia de El Niño 1983. Se entrega una clave que considera sólo los caracteres externos más conspicuos de estas larvas, sin la disección de los ejemplares. Estas familias representan un tercio del total que viven en el área bajo condiciones oceanográficas normales. A nivel de especies, las 22 recolectadas constituyen casi la séptima parte del total de 150. Las especies introducidas en el área por la influencia de aguas más septentrionales pertenecen a las familias Penaeidae y Sicyoniidae. Las larvas recolectadas pertenecen principalmente a aguas intermareales y sublitorales.
\end{abstract}

Palabras claves: claves, crustáceos decápodos, larvas, Fenómeno El Niño, Chile.

\section{INTRODUCTION}

Larval development of decapod crustaceans is perhaps one of the most important pieces of their life cycle. The larval condition implies a total change in the style of life of the organisms as members from the benthic or pelagic communities when they pass to integrate part of the plankton. Morphologic change facilitates dispersion. Many times it is the principal source of the geographic and bathymetric distribution of the species as adults. Larval morphology represents additional taxonomic elements for their specific identification. In many cases, morphological features of larvae are complementary characters necessary for the understanding of the evolution of the species. Success in the larval life is one of the principal determinants for a successfull recruitment and it is an important element to evaluate a species fishery.

The decapod crustaceans recognized here as families are larvae that survived the impact of an unprecedented strong intensity El Niño event (198283). Characteristics and effects of this event on the South Eastern Pacific marine biota have been detailed documented (Arntz, 1984; Arntz and Valdivia, 1985a, 1985b; Báez, 1985; Méndez, 1987).

\footnotetext{
${ }^{1}$ Partially financed by a fellowsship from the Deutscher Akademischer Austauschdienst (DAAD)
} 
The captured larvae represent a small fraction from a greater number of families that live in the sampled area under "normal" oceanographic conditions (Báez and Martin, 1992).

The main objetives of this paper have been to document the event to serve as a reference point for later comparisons, either with the meroplankton of the area collected during an El Niño event and with material obtained from palaeoenvironmental research or from normal years.

\section{MATERIALS AND METHODS}

The material consists of 44 samples collected along 11 parallel eastwest transects (4 stations each) taken between $18^{\circ} 38^{\prime} 00^{\prime} ' \mathrm{~S}$ and $28^{\circ} 04^{\prime} 00^{\prime}$ 'S from near coast ( $5 \mathrm{~km}$ offshore) to about $200 \mathrm{~km}$ west approximately, between Arica and Puerto Huasco, northern Chile.

Samples were collected by means of a WP2 net (UNESCO, 1968) with an internal mouth diameter of $57 \mathrm{~cm}$, a total length of $261 \mathrm{~cm}$, and a mesh size of 300 microns. Depth ranged between 0-74 and 0-100 m. Additional data on collecting techniques and cruise data have been published elsewhere (Rojas and Orellana, 1984; Báez and Martin, 1992).

Plankton samples were preserved in 5\% formalin prepared with seawater and divided in 4 aliquots using a Folsom apparatus. Decapod larvae were removed and studied from two of the four quarters per sample.

Here I present only those characters possible of being determined without dissection, having in mind to use the key for preliminary sortings. Also, the characters used in the key are those that do not change significantly through the successive larval stages. Larval identification of the stages was as follows (Penaeiodea: nauplius, protozoea, mysis, and postlarva; Caridea, Thalassinidea, Brachyura and Anomura: prezoea, zoeae and megalopa). I followed descriptions made by Palma and Kaiser (1993) considering mysis and postlarva to be equivalent with zoea and megalopa, respectively.

Identification of the larvae to the family level was accomplished by using published literature on the larval development of Chilean decapod species (e.g., Fagetti, 1960, 1970; Fagetti and Campodonico 1971a, 1971b; Quintana and Saelzer, 1986). Also, personal unpublished observations were used. Those species for which larval stages have not been described yet, or that were new for the area, were identified from the literature describing related taxa from other geographic areas. More details and references used to identify larvae at different taxonomic levels are in Báez and Martin (1992), Boschi (1981), Bourdillon-Casanova (1960), Gurney (1939, 1942), Hart (1971), Rice (1980); Scelzo (1976), Williamson (1957a, 1957b, 1960, 1982) and Wear (1970).

\section{RESULTS}

\section{KEY TO THE LARVAL STAGES OF DECAPOD CRUSTACEANS FOUND IN EL NIÑO EVENT}

1. Contour of the body as a simple pear shape form. With a simple median eye in th anterior region of the body. Nauplius (Fig. 1a)

- Contour of the body not as above. With coumpound eyes..........................................2

2. Carapace not covering completely the thorax (some thoracic terga remaining free). Antennal exopod segmented to base..........Protozoea (Fig. 1b)

- Carapace covering completely the thorax (thoracic terga completely covered). Antennal exopod unsegmented or segmental at tip only.

3. Without well-development pleopods. Swimming by maxilliped exopods......Zoea (Fig. 1c)

- Whit at least one pair of well - developed pleopods. Swimming by swimming - legs......4

4. Shrimp-like shape. Pereipods with well developed exopods...........................Mysis (Fig. 1d)

- Crab-like shape. Pereipods without welldeveloped exopods. Megalopa (Fig. 1e)

\section{KEY TO THE FAMILIES OF DECAPOD CUSTACEANS RECORDED AS ZOEA, OR MYSIS FROM THE PLANKTON DURING AN EL NIÑO EVENT}

1. Body with carapace markedly globular, abdomen thin and relatively short. Swimming setae restricte to exopodite of first and second maxillipeds. 

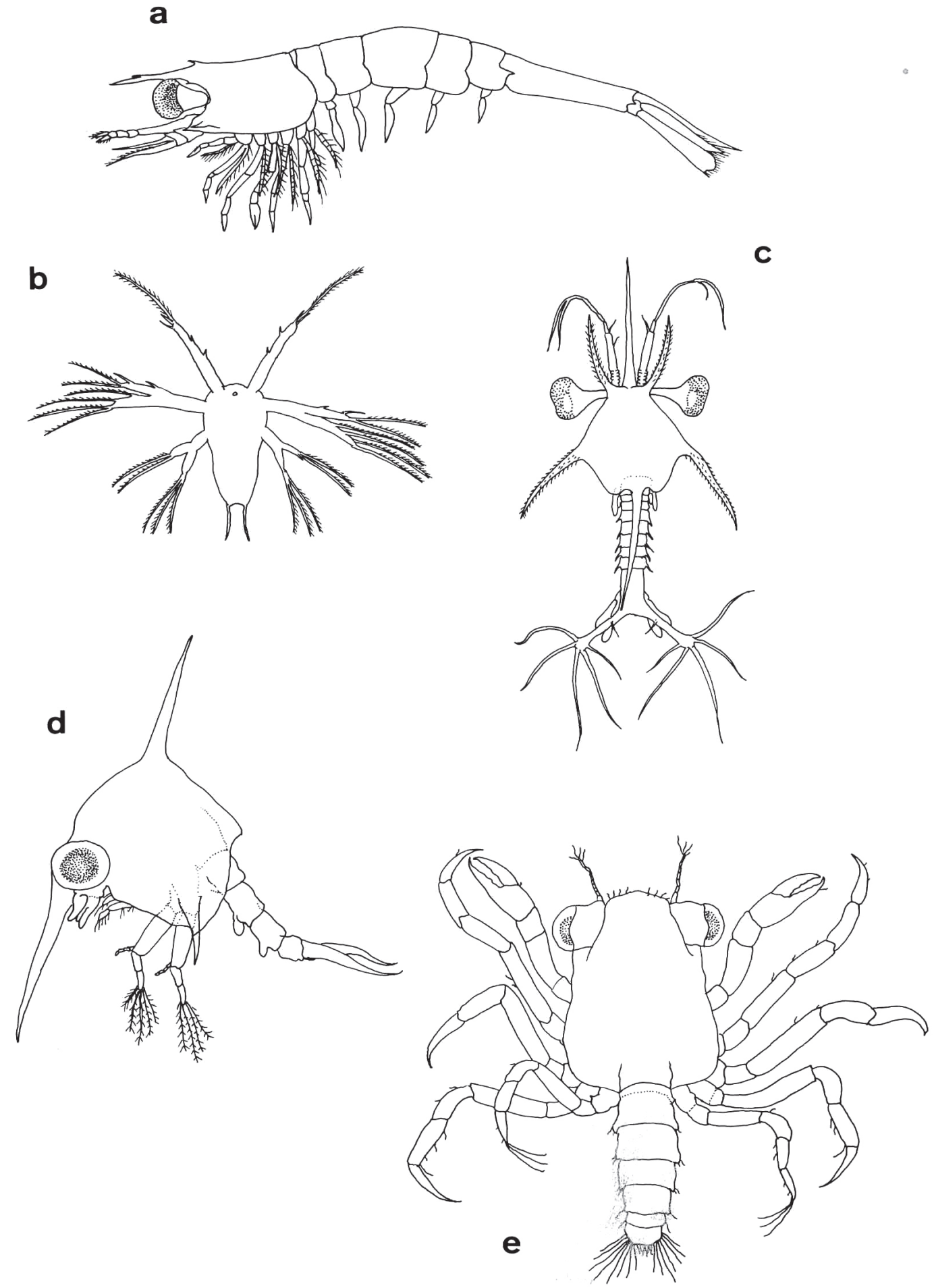

$c$

Figure 1. Types of decapod crustacean larval stages collected off northern Chile during El Niño 1982-83 event. a. Mysis, b. Nauplius, c. Protozoea, d. Zoea, e. Megalopa.

Figura 1. Tipos de larvas de crustáceos decápodos recolectados en el norte de Chile durante el evento EI Niño 1982-83. a. Mysis, b. Nauplius, c. Protozoea, d. Zoea, e. Megalopa. 

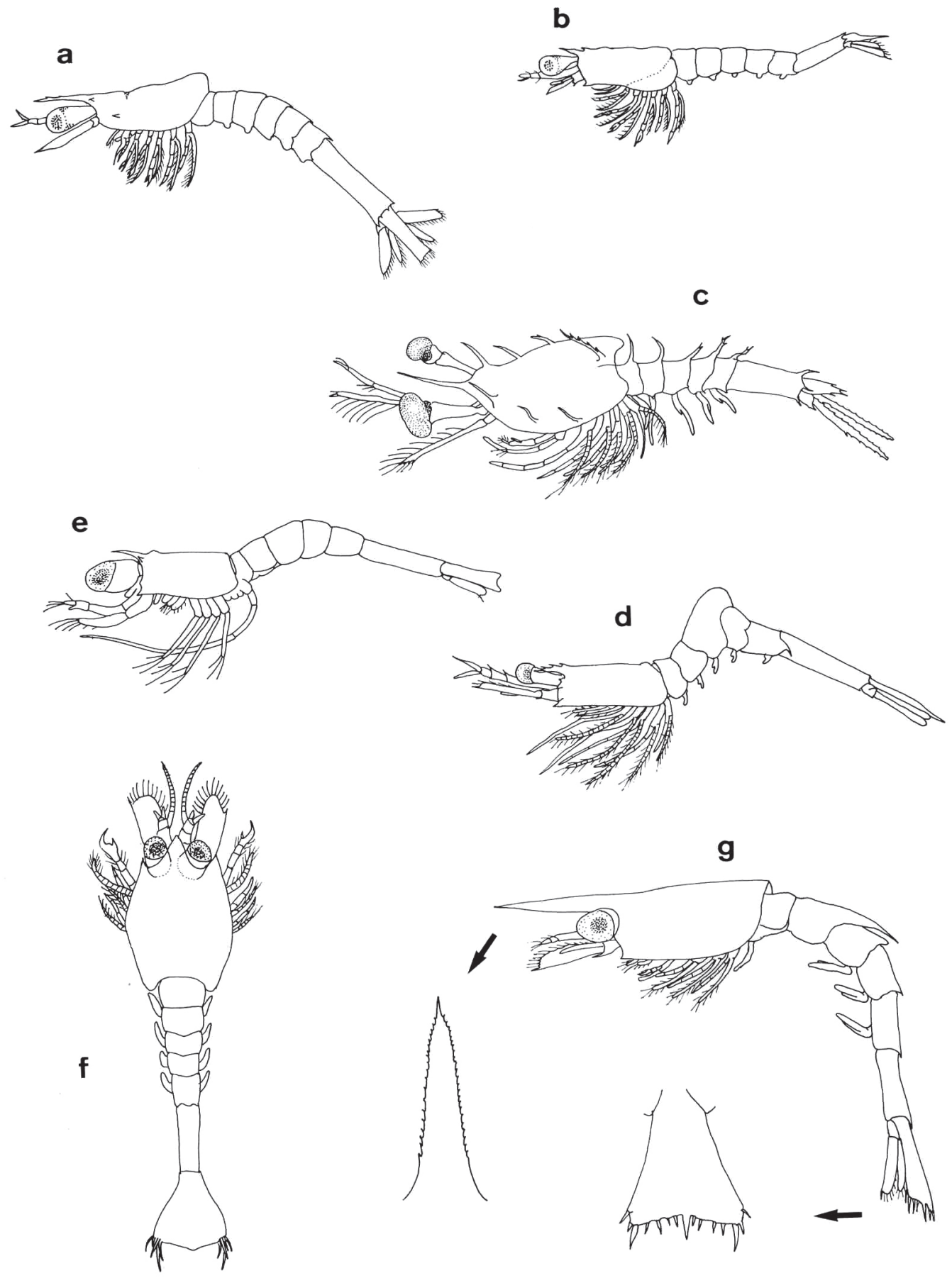

Figure 2. Mysis from the families of decapod crustaceans collected during EI Niño 1982-83 event: Suborders. Dendrobranchiata and Pleocyemata (Infraorders Caridea, Astacidea, Thalassinidea). a. Penaeidae, b. Sicyoniidae, c. Sergestidae, d. Oplophoridae, e. Alpheidae, f. Crangonidae, g. Callianassidae.

Figura 2. Mysis de familias de crustáceos decápodos recolectados durante el evento El Niño 1982-83: Subórdenes. Dendrobranchiata y Pleocyemata (Infraórdenes Caridea, Astacidea, Thalassinidea). a. Penaeidae, b. Sicyoniidae, c. Sergestidae, d. Oplophoridae, e. Alpheidae, f. Crangonidae, g. Callianassidae. 
- $\quad$ Body with carapace markedly cylindrical; abdomen well developed, relatively long. Swimming setae on more than first and second maxillipeds.

2. With developing chelae of similar size on pereiopods 1-3. Without a spine near middle or outer side of margin exopod from each uropod.......3

- Whitout chelae, subchelated, or if with developing chelae only on pereiopods 1-2. With a spine near middle of each uropod outer margin.

3. Carapace antero-lateral borders with spines. Telson not deeply forked...Penaeidae (Fig. 2a)

- Carapace antero-lateral borders without spines. Telson deeply forked ....Sicyoniidae (Fig. 2b)

4. Carapace with several large lateral spines, some dorsal spines, and one median spine posteriorly, in addition to large supraorbital and rostral spines. Abdominal somites with large lateral and/or dorsal spines ..Sergestidae (Fig. 2c)

- Carapace not as above. Abdominal somites, without spines or with very small spines........5

5. All pereiopods with exopods. Abdominal somite 4 projected into a rounded hump.

.Oplophoridae (Fig. 2d)

- $\quad$ Not all pereiopods with exopods. Abdominal somite 4 not projected into a rounded hump

...6

6. Rostrum relatively thin and laterally compressed. Fifth pereiopods longer than the others.

Alpheidae (Fig. 2e)

- $\quad$ Rostrum relatively wide and depressed. Fifth pereiopods no longer than the others............7

7. Ocular peduncles hemispheric and almost touching each other on medial line. Distal margin of telson tending to be convex, without a large medial spine......Crangonidae (Fig. 2f)

- Ocular peduncles not hemispheric and well separated each other on medial line. Distal margin of telson tending to be concave, with a large medial spine... .Callianasidae (Fig. 2g)

8. Carapace tending to be oval-shaped. Without a"cephalic" or "dorsal" spine. 9 Carapace tending to be spherical. With a "cephalic" or "dorsal"spine. 12
9. Carapace without lateral spines. Telson with round or convex distal margin and with a small spine on each side. .10

- Carapace with lateral spines thin and long. Telson divided and/or concave on distal margin and with a strong spine on each side. .11

10. Posterior margin of the carapace not serrated. Abdominal somites with spines on posterior margins

.Paguridae (Fig. 3a)

Posterior margin of the carapace serrated. Abdominal somites without spines on posterior margins

Galatheidae (Fig. 3b)

11. Rostral spine at least twice as long as carapace and lateral-posterior spines or processes as long as or longer than carapace. Distal margin of telson with long setae.......Porcellanidae (Fig. 3c)

- Rostral spine less than twice as long as carapace and lateral-posterior spines or processes not as long as carapace. Distal margin of telson with short spines.............................Hippidae (Fig. 3d)

12. Rostral spine length equal to, or longer, than carapace length. Dorsal or cephalic spine length equal to, or longer, than carapace length......13

- $\quad$ Rostral spine length less than carapace length. Dorsal or cephalic spine length less than carapace length.

14

13. Abdominal somites 3 to 5 with lateral-posterior spines, whose lengths are notoriously more than half of the somite length. Antennal length equal to $3 / 4$, or more, of rostrum length

Atelecyclidae (Fig. 3e)

- Abdominal somites 3 to 5 with lateral-posterior spines, which are notorious in later stages, but their lengths are a little more than half the somite length. Antennal length less than $3 / 4$ of rostrum length

Cancridae (Fig. 3f)

14. Telson fork short and without accessory lateral spines. Abdomen segments 3 to 5 with short lateral-posterior spinous processes or spines .Grapsidae (Fig. 3h)

- $\quad$ Telson fork long and often spinulose, usually with at least one accessory spine. Abdomen segments 3 to 5 with long lateral-posterior processes or spines .Xanthidae (Fig. 3g)

The diversity of decapod crustaceans species living as adults in northern Chile at the sampled area 


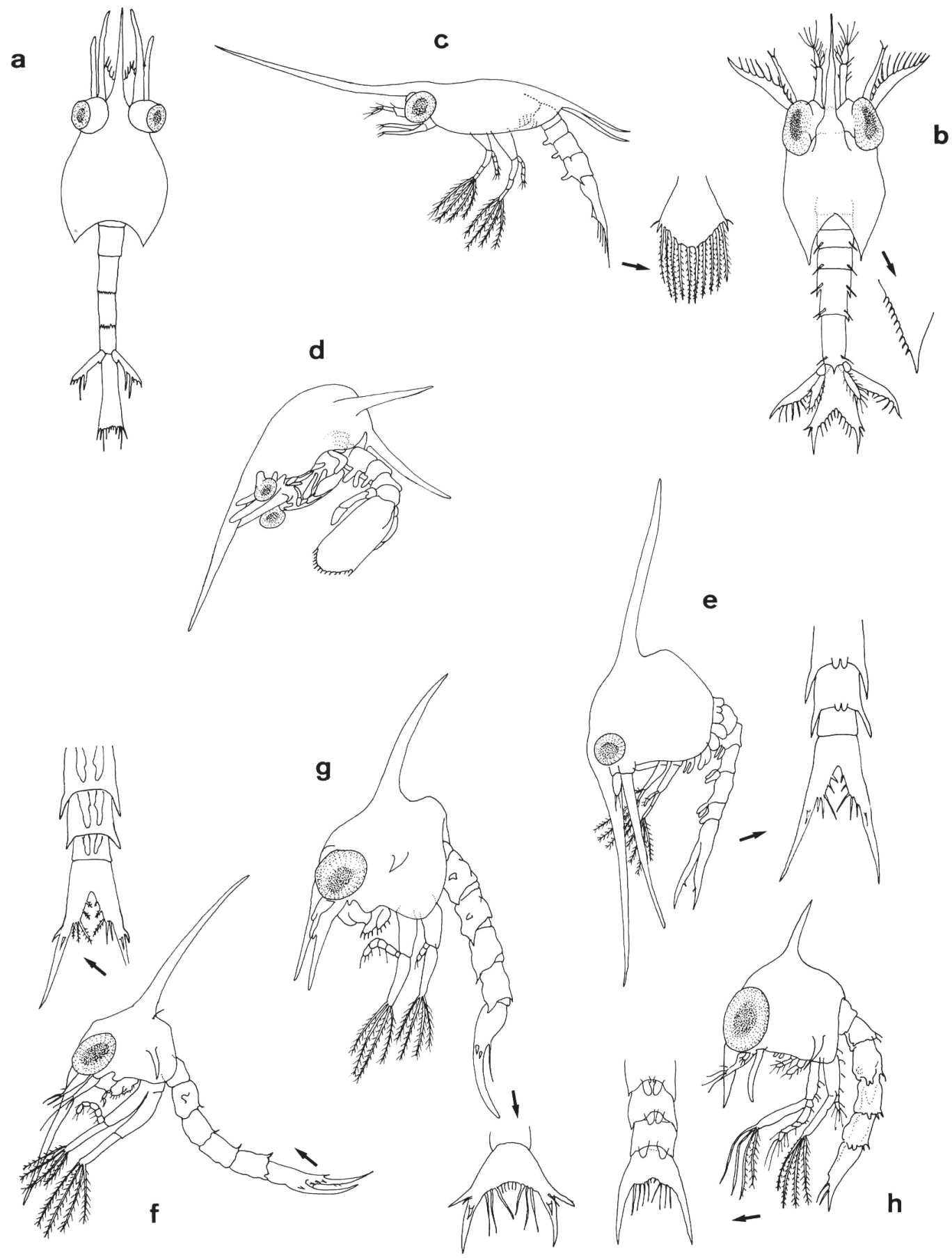

Figure 3. Zoeae from the families of decapod crustaceans collected during El Niño 1982-83 event: Suborder Pleocyemata Infraorder Anomura: a. Paguridae, b. Galatheidae, c. Porcellanidae, d. Hippidae. Infraorder Brachyura: Atelecyclidae, f. Cancridae, g. Xanthidae, h. Grapsidae.

Figura 3. Zoeas de familias de crustáceos decápodos recolectados durante el evento El Niño 1982-83: Suborden Pleocyemata Infraorden Anomura: a. Paguridae, b. Galatheidae, c. Porcellanidae, d. Hippidae. Infraorden Brachyura: Atelecyclidae, f. Cancridae, g. Xanthidae, h. Grapsidae. 
Table 1. Families of decapod crustaceans living as adults in northern Chile.

Tabla 1. Familias de crustáceos decápodos cuyos adultos viven en el norte de Chile.

\begin{tabular}{|c|c|c|c|c|c|c|c|}
\hline \multirow[b]{2}{*}{ Family } & \multicolumn{5}{|c|}{ Bathymetric zones } & \multirow[b]{2}{*}{$\mathbf{N}^{\circ}$ sp. } & \multirow[b]{2}{*}{ EN } \\
\hline & $\mathbf{I}$ & $\mathbf{S}$ & $\mathbf{A}$ & $\mathbf{P}$ & $\mathbf{K}$ & & \\
\hline \multicolumn{8}{|c|}{ Suborder Dendrobranchiata } \\
\hline \multicolumn{8}{|c|}{ Infraorder Penaeoidea } \\
\hline Penaeidae & - & + & - & - & - & 1 & + \\
\hline Sicyoniidae & - & + & + & - & - & 1 & + \\
\hline Sergestidae & - & - & - & + & - & 2 & + \\
\hline Aristeidae & - & - & + & - & - & 1 & - \\
\hline Solenoceridae & - & - & + & - & - & 1 & - \\
\hline
\end{tabular}

Suborder Pleocyemata

Infraorder Caridea

Oplophoridae

Pasiphaeidae

Rhynchocinetidae

Campylonotidae

Palaemonidae

Alpheidae

Hippolytidae

Pandalidae

Crangonidae

Glyphocrangonidae

Infraorder Astacidea

Nephropsidae

Infraorder Thalassinidea

Callianassidae $\quad-\quad+\quad+\quad-\quad+\quad+\quad+\quad+$

Infraorder Palinura

Polychelidae

Infraorder Anomura

Coenobitidae

Diogenidae

Lithodidae

Paguridae

Parapaguridae

Chirostylidae

Galatheidae

Porcellanidae

Albuneidae

Hippidae

Infraorder Brachyura

Homolodromiidae

Calappidae

Leucosiidae

Majidae

Hymenosomatidae

Atelecyclidae

Cancridae

Corystidae

Portunidae

Platyxanthidae

Xanthidae

Grapsidae

Pinnotheridae

Ocypodidae

Total $14 \quad 24$

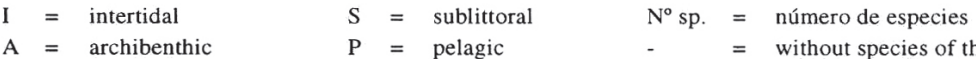

$\mathrm{A}=$ archibenthic $\quad \mathrm{P}=$ pelagic
$+\quad=$ one or more species of the family living in the zone

$\mathrm{K}=$ existing knowledge on larvae based on species living in Chilean waters

$\mathrm{EN}=$ species occurring as larvae in the area during the El Niño 1982-1983 event 
reaches today to 151 species under "normal" oceanographic conditions (Table I). Six of them are Dendrobranchiata and 144 are Pleocyemata. They totalize 42 families some of which are benthic, other pelagic. The benthic ones have species that can be intertidal, sublittoral or archibentic. Some of them can live within wider bathymetric limits occupying two of the three cited zones. Only five families belong exclusively to the oceanic realm. From the total of larvae reported from the area, only 22 species belonging to 15 families, were encountered during El Niño 1982-83 event.

\section{DISCUSSION}

Larval development of decapod crustaceans living in Chilean waters is still unknown for the majority of species (Wehrtmann and Báez, 1997). The existing knowledge of the larvae from the decapod Crustacea of Chile derives mainly from laboratory larval rearing experiments, and, secondarily, from larvae taken from the plankton. Unfortunately, from the larva obtained from the plankton, no mention has never been made if they were collected under normal or "abnormal" El Niño conditions. The paper and a previous one (Báez and Martin, 1992) represent the first contribution to understand the effect on decapod larvae of a notoriuos seawater temperature elevation. It will allow comparisons with planktonic material captured under "normal" conditions and with larval vestiges obtained through palaeoenvironmental investigations.

Zoeae were the most frequently found and easily sorted larval stage. Nevertheless, some morphological and morphometrical variability was noticed comparing zoea specimens with those from the literature, as it has been reported within the family Xanthidae by Wear (1970) and for the species from the subfamily Sesarminae, among the Grapsidae by Costlow and Fagetti (1967), and among many others papers.

Nauplii, protozoeae and megalopae were found only occassionally. The total of 22 species found belong to 17 genera. They represent, at a specific level, almost one fifth of the total of species living in the area and two thirds at a familial level. Among them only the following genera, and some few species were identified: Xiphopenaeus (X. rivetti), Penaeus, Sicyonia, Sergestes, Sergia, Acanthephyra, Callianassa, Pleuroncodes, Cancer sp. (Species "A" and C. edwardsii), Homalaspis ( $H$. plana), Cyclograpsus (C. punctatus). No conspicuous differences were found, either in general shape or color, between these larvae and those captured or cultured under normal colder conditions.

Species introduced in the area as larvae by El Niño were: Xiphopenaeus rivetti Bouvier, 1907, ranging from Sinaloa, México, to Paita, Per $\{\mathrm{u}$ as a benthic shrimp that lives off the river mouth and on the continental shelf to $70 \mathrm{~m}$ depth (Chirichigno, 1970; Pérez y Farfante, 1970). Its nauplius stage, selected by discard and confirmed with its range extention as adult to Pisco, Perú (Vélez and Zeballos, 1985), extended its distribution to the reported Chilean northern waters under these El Niño conditions. The family Sicyoniidae has been cited by Méndez (1981) for Perú by the genus Sicyonia with four species: S. aliaffinis, S. disdorsalis, $S$. affinis and S. picta. From them Sicyonia disdorsalis and S. aliaffinis extend their limits more to the south (Vélez and Zeballos, 1985) and would appear as more problable for them to live in the sampled area during El Niño events.

\section{ACKNOWLEDGEMENTS}

My thanks are due to Prof. Dr. Wolf Arntz and Dr. Stefan Wellerhaus, both from the Alfred Wegener Institut für Polar und Meeresforschung of Germany, and to Dr. Joel W. Martin, Curator of Crustacea from the Natural History Museum of Los Angeles County Museum, U. S. A., their help to identify the larvae. To Dr. Ingo Wehrtmann from Universidad Austral de Chile, Valdivia, his critical revision of the manuscript.

\section{REFERENCES}

Arntz, W.E. 1984. El Niño and Perú: Positive aspects. Oceanus, 27: 36-39.

Arntz, W.E. y E. Valdivia. 1985a. Visión integral del problema "El Niño". Introducción. Bol. Inst. Mar, Perú, Volumen extraordinario: 5-10.

Arntz, W.E. y E. Valdivia. 1985b. Incidencia del fenómeno "El Niño" sobre los mariscos en el litoral peruano. Bol. Inst. Mar Perú-Callao, Volumen extraordinario: 91-101.

Báez, P. 1985. Fenómeno El Niño, elemento importante en la evolución del camarón de río (Cryphiops caementarius). Invest. Pesq. (Chile), 32: 235-242. 
Báez, P. y J.W. Martín. 1992. Decapod Crustacea larvae collected off northern Chile during an El Niño event (February-March, 1983). Contributions in Science, Natural History Museum of Los Angeles County (432): 1-10.

Boschi, E.E. 1981. Larvas de Crustacea Decapoda. In: D. Boltoskoy (ed.) Atlas del zooplancton del Atlántico Suboccidental y métodos de trabajo con zooplancton marino. Publicación especial del INIDEP, Mar del Plata, Argentina, pp. 699-758.

Bourdillon-Casanova, L. 1960. Le meroplancton du Golfe de Marseille: les larves de Crustacés Décapodes. Rec. Trav. St. Mar. Endoume, 30: 1286.

Chirichigno, N. 1970. Lista de crustáceos del Perú (Decapoda y Stomatopoda) con datos de su distribución geográfica. Inf. Inst. Mar Perú-Callao, 35: $1-95$.

Costlow, J. y E. Fagetti. 1967. The larval development of the crab, Cyclograpsus cinereus Dana, under laboratory conditions. Pacific Sci., 21(2): 166-177.

Fagetti, E. 1960. Primer estadio larval de cuatro crustáceos braquiuros de la bahía de Valparaíso. Rev. Biol. Mar., Valparaíso, 10: 143-154.

Fagetti, E. 1970. Desarrollo larval en el laboratorio de Homalaspis plana (Milne-Edwards) (Crustacea Brachyura: Xanthidae). Rev. Biol. Mar., Valparaíso, 14(2): 29-49.

Fagetti, E. y I. Campodonico. 1971a. Larval development of the red crab Pleuroncodes monodon (Decapoda Anomura: Galatheidae) under laboratory conditions. Mar. Biol., 8: 70-81.

Fagetti, E. y I. Campodonico. 1971b. The larval development of the crab Cyclograpsus punctatus H. Milne Edwards, under laboratory conditions (Decapoda, Brachyura, Grapsidae, Sesarminae). Crustaceana, 21, Part 2: 183-195.

Gurney, R. 1939. Bibliography of the larvae of decapod Crustacea. London Royal Society, 123 pp.

Gurney, R. 1942. Larvae of decapod crustacea. London Royal Society, 306 pp.

Hart, J. 1971. Key to planktonic larvae of families of decapod Crustacea of British Columbia. Syesis, 4: 227-234.

Méndez, M. 1981. Claves de identificación y distribución de los langostinos y camarones (Crustacea: Decapoda) del mar y ríos de la costa del Perú. Bol. Inst. Mar Perú-Callao, 5: 170 pp.
Méndez, R. 1987. Cambios bióticos y efectos sobre los recursos pesqueros y pesquerías de Chile. Rev. Com. Perm. Pacífico Sur, 16: 7-96.

Palma, S. y K. Kaiser. 1993. Plancton marino de aguas chilenas. Ed. Universitarias de Valparaíso, Universidad Católica de Valparaíso, 151 pp.

Pérez Farfante, I. 1970. Claves ilustradas para la identificación de los camarones comerciales de la América Latina. Instituto Nacional de Investigaciones Biológico-Pesqueras, México, Serie Divulgación, Instructivo 3: 1-50.

Quintana, R. y H. Saelzer. 1986. The complete larval development of the edible crab, Cancer setosus Molina and observations on the prezoeal and first zoeal stages of $C$. coronatus Molina (Decapoda: Brachyura, Cancridae). J. Fac. Sci., Hokkaido Univ., Ser. VI, zool., 24 (4): 267-303.

Rice, A.L. 1980. Crab zoeal morphology and its bearing on the classification of the Brachyura. Trans. Zool. Soc. London, 35: 271-424.

Rojas, O. y A.E. Orellana. 1984. Estudio del zooplancton del norte de Chile, durante Febrero y Marzo de 1983. Inf. téc., Inst. Fom. Pesq., Santiago, $20 \mathrm{pp}$.

Scelzo, M. 1976. Larvas de los crustáceos decápodos anomuros, identificadas en las aguas marinas argentinas. Physis, Sección A, 35(90): 37-45.

Organización de Naciones Unidas para la Educación, las Ciencias y la Cultura (UNESCO). 1968. Zooplancton sampling. UNESCO Monographs on Oceanographic Methodology, 2: 174 pp.

Vélez, J. y J. Zeballos. 1985. Ampliación de la distribución de algunos peces e invertebrados durante el fenómeno "El Niño" 1982-1983. Bol. Inst. Mar Perú-Callao. Volumen extraordinario, pp. 173-180.

Wear, R. 1970. Notes and bibliography on the larvae of xanthid crabs. Pacific Sci., 24(1): 84-89.

Wehrtmann, I. y P. Báez. 1997. Larvas y estadíos tempranos de desarrollo de crustáceos decápodos de Chile: descripciones publicadas. Invest. Mar, Valparaíso, 25: 263-276.

Williamson, D.I. 1957a. Crustacea, Decapoda: Larvae, V. General. Fiches Identification Zooplancton, 67: $1-7$. 
Williamson, D.I. 1957b. Crustacea, Decapoda: Larvae, V. Caridea, family Hippolytidae. Fiches Identification Zooplancton, 68: 1-5.
Williamson, D.I. 1960. Crustacea, Decapoda: Larvae, VII. Caridea, family Crangonidae: Stenopodidea. Fiches Identification Zooplancton, 90: 1-5.

Williamson, D.I. 1982. Larval morphology and diversity. In: L.G. Abele (ed.), Biology of Crustacea. Vol. 2. Embriology, morphology and genetics. Academic Press, New York, pp. 43-110.

Recibido el 17 de julio de 1996.

Aceptado el 23 de enero de 1997. 